\title{
Author Correction: Comparison of bacterial microbiota of the predatory mite Neoseiulus cucumeris (Acari: Phytoseiidae) and its factitious prey Tyrophagus
putrescentiae (Acari: Acaridae)
}

Apostolos Pekas ${ }^{1}$, Eric Palevsky ${ }^{2}$, Jason C. Sumner ${ }^{3}$, M. Alejandra Perotti ${ }^{4}$, Marta Nesvorna $^{5}$ \& Jan Hubert ${ }^{5}$

Correction to: Scientific Reports https://doi.org/10.1038/s41598-017-00046-6, published online 31 January 2017

The original version of this Article contained an error in Affiliation 3 which was incorrectly listed as 'SASA (Science and Advice for Scottish Agriculture), 1 Roddinglaw Road, Edinburgh, EH9 2BR, UK'.

The correct affiliation is listed below:

'SASA (Science and Advice for Scottish Agriculture), 1 Roddinglaw Road, Edinburgh, EH12 9FJ, UK'.

This error has now been corrected in the HTML and PDF versions of the Article.

(c) (i) Open Access This article is licensed under a Creative Commons Attribution 4.0 International cc) License, which permits use, sharing, adaptation, distribution and reproduction in any medium or format, as long as you give appropriate credit to the original author(s) and the source, provide a link to the Creative Commons license, and indicate if changes were made. The images or other third party material in this article are included in the article's Creative Commons license, unless indicated otherwise in a credit line to the material. If material is not included in the article's Creative Commons license and your intended use is not permitted by statutory regulation or exceeds the permitted use, you will need to obtain permission directly from the copyright holder. To view a copy of this license, visit http://creativecommons.org/licenses/by/4.0/.

(C) The Author(s) 2018

\footnotetext{
${ }^{1}$ Research \& Development Department, Biobest Belgium N. V., Ilse Velden 18, Westerlo, B-2260, Belgium. ${ }^{2}$ Department of Entomology, Newe-Ya'ar Research Center, Agricultural Research Organization, Ministry of Agriculture, P.O. Box 1021, Ramat Yishay, IL-30095, Israel. ${ }^{3}$ SASA (Science and Advice for Scottish Agriculture), 1 Roddinglaw Road, Edinburgh, EH12 9FJ, UK. ${ }^{4}$ Evolutionary Biology Section, School of Biological Sciences, University of Reading, Reading, RG6 6AS, UK. ${ }^{5}$ Crop Research Institute, Drnovska 507/73, Prague 6-Ruzyne, CZ-161 06, Czechia, Czech Republic. Correspondence and requests for materials should be addressed to J.H. (email: hubert@vurv.cz)
} 